\title{
MEASURING THE ROLLING RESISTANCE OF PNEUMOBILES
}

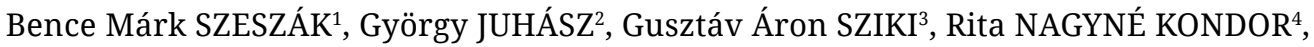 \\ Tamás Sádor SÜTŐ ${ }^{5}$, Krisztián József VESZELSZKI ${ }^{6}$ \\ University of Debrecen, Faculty of Engineering, Department of Mechanical Engineering, Debrecen, Hungary \\ ${ }^{1}$ szeszakbence@gmail.com \\ ${ }^{2}$ juhasz@eng.unideb.hu \\ ${ }^{3}$ szikig@eng.unideb.hu \\ ${ }^{4}$ rita@eng.unideb.hu \\ ${ }^{5}$ suto.tamas28@gmail.com \\ ${ }^{6}$ vkrisz992@gmail.com
}

\begin{abstract}
In this publication we present a vehicle dynamic model and the motion of equation for pneumobiles. One of the input parameters of the model is the rolling resistance coefficient of the tyres. The present publication describes the experimental setup and work in the course of which the above coefficient was measured and the effect of tyre pressure on rolling resistance was analysed. During the measurement, we examined the effect of tyre pressure on rolling resistance, including when the vehicle in unloaded and in loaded state.
\end{abstract}

Keywords: rolling resistance, pneumobile, alternative powered vehicle, Spider8 measuring system, compressed air.

\section{Introduction}

We performed the measuring of the rolling resistance [1] on a pneumobile which has been designed and built by the DE - Főnix pneumobil team for the IX. International Aventics Pneumobile Competition at the University of Debrecen Faculty of Engineering. Figure 1. shows the pneumobil.

A simulation program for the calculation of the vehicle dynamic functions of the mobile from its technical data has been also developed in previous years. One of the required input parameters of the program is the rolling resistance coefficient of the tyres.

\section{The equation of motion of the vehicle}

In previous years the motor characteristics curve of a self-developed pneumobile was determined and the equation of motion of the vehicle

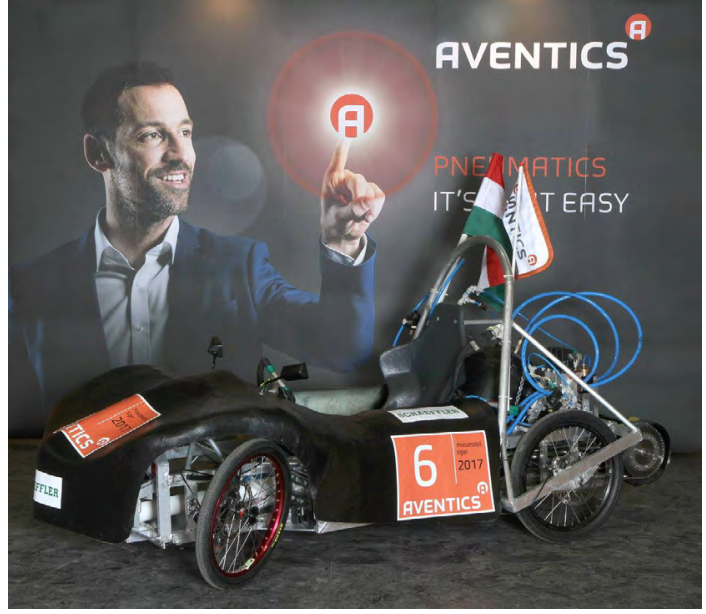

Figure 1. The pneumobile

was solved [2]. Figure 2. shows the different forces acting on the mobile during its motion. 


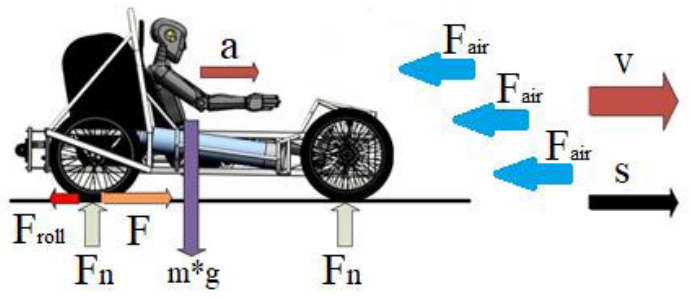

Figure 2. Forces acting on the mobile

On the bases of Figure 2. the motion equation of the pneumobile is as follows:

$$
\sum F=F(v)+F_{\text {roll }}+F_{\text {air }}=m \cdot a
$$

In the above equation Froll is the rolling resistance which is calculated by the following formula:

$$
F_{\text {roll }}=c \cdot m \cdot g
$$

where:

$-F_{\text {roll }} \quad$ is the rolling resistance;

$-c$ is the rolling resistance coefficient of the tyres;

$-m \quad$ is the mass of the vehicle;

$-g \quad$ is the standard gravity.

\section{Materials and methods}

The applied measuring system - which is built up of five subunits - is shown in Figure 3.

Pneumobile (1): We performed the measurements on that vehicle.

Load cell (2): The load cell was fixed to the vehicle by an M5 threaded stem firmly. To the load cell a tow rope was attached through a self-made threaded sleeve to ensure the cell's one axle loading which is a prerequisite for precise measurement.

Worm gear (3): To ensure an adequate and constant traction force, thus velocity, the tow rope

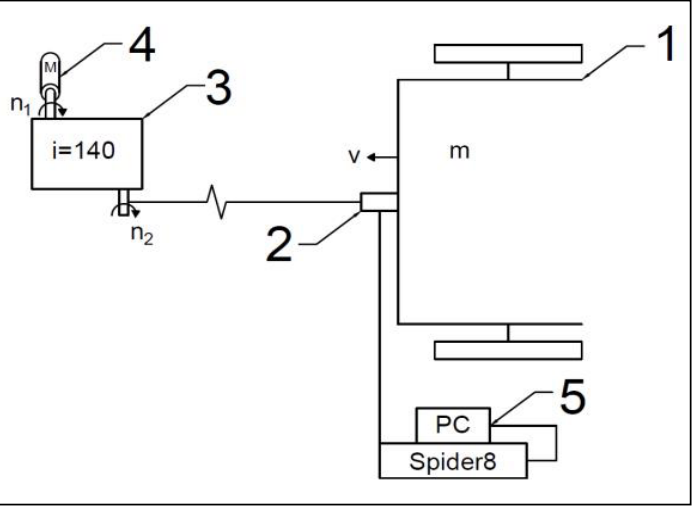

Figure 3. Schematic view of the measuring system was pulled by means of a worm gear. The worm gear was fixed to a wooden base firmly to ensure its stability.

Drive (4): The worm gear was driven by a Metabo SBE570 type electric drill. The drill was operated at its maximum angular speed of 3000 [1/min]. Measuring system and electronics (5): A Spider8 multi-channel PC measurement electronics unit was applied using its own software.

\section{Results}

During the measurement, we examined the effect of tyre pressure on rolling resistance, even when the vehicle was in an unloaded and loaded state. At each pressure, 10 measurements were made. In unloaded condition we examined the rolling resistance at four different tire pressure values. These were 1, 3, 5 and 7 [bar]. The coefficient of rolling resistance of a loaded pneumobile (weight of $650 \mathrm{~N}$ ) has been measured at 13 different tyre pressures between 1 and 7 [bar] in 0.5 bar steps. At each pressure, 10 measurements were made and the average and standard deviation of the data were calculated. The obtained results are presented in Figure 4. and Figure 5.

\section{Conclusions}

The coefficient of rolling resistance of an unloaded pneumobile has been measured at 4 different tyre pressure between 1 and 7 [bar] in 2 bar steps. The loaded pneumobile has been measured at 13 different tyre pressures between 1 and 7 [bar] in 0.5 bar steps. The model function has been fitted well to the measured data [5]. The above function - or the original data in the form of "Look up table” - will be built into our MATLAB/SIMULINK program enabling the calculation of rolling resistance coefficient directly from tyre pressure (Figure 6.). In the near future we intend to study also the effect of load on rolling resistance coefficient. From the measurement results, it appears that the difference between the mid values is not as drastic as the values of the lowest and the highest tyre pressure, but it can still be detected.

The obtained results are used in further dynamic modelling of the vehicle. In the future, it is possible to simulate and optimize the pneumobile in more realistic conditions. 


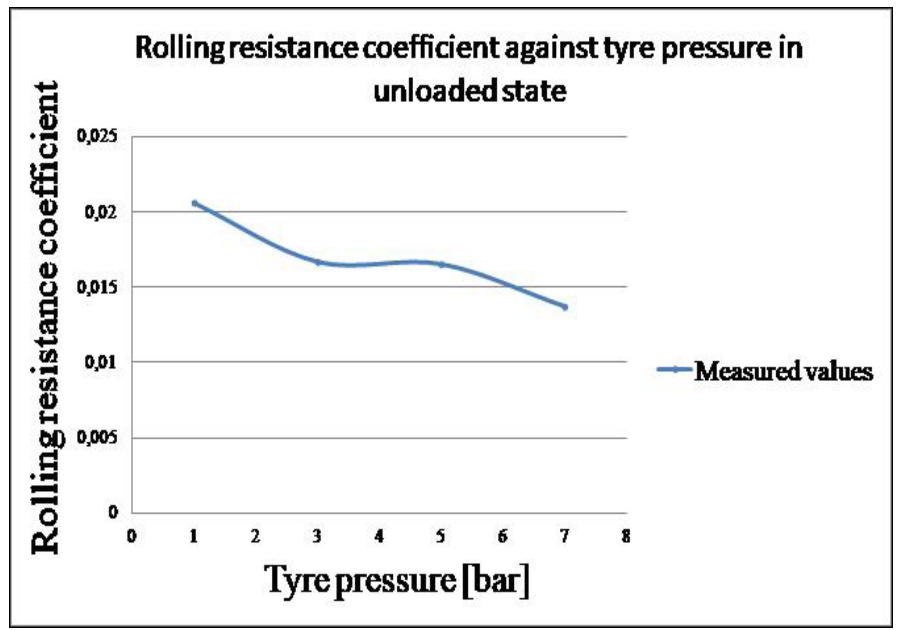

Figure 4. Rolling resistance coefficient against tyre pressure in unloaded state [3]

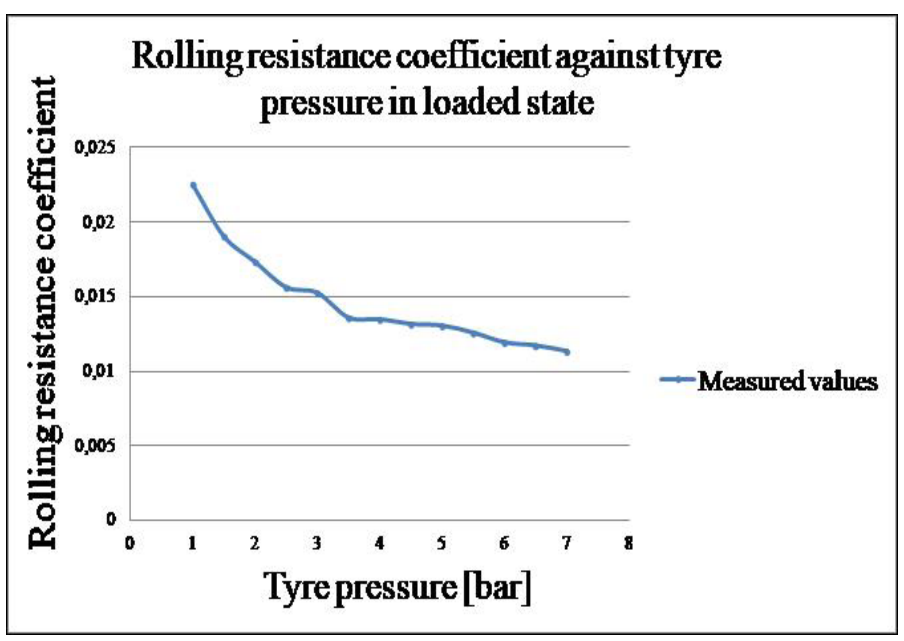

Figure 5. Rolling resistance coefficient against tyre pressure in loaded state [4]

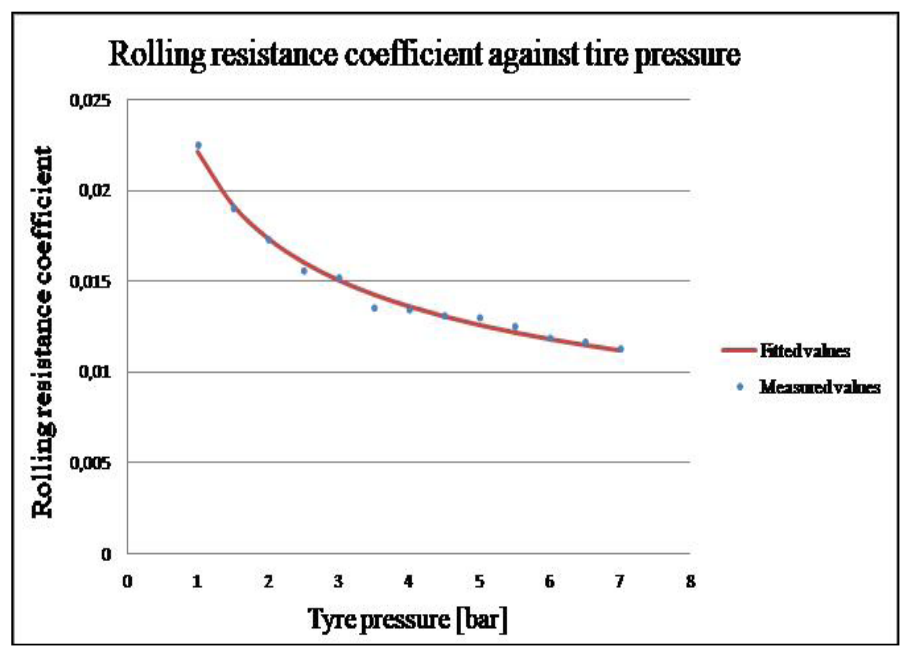

Figure 6. Rolling resistance coefficient against tyre pressure and fitted values 


\section{References}

[1] Szeszák B. M.: Pneumobil gördülési ellenállásának mérése. Thesis, Debrecen, 2017.

[2] Juhász B.: Számítógépes program a pneumobil menetdinamikai paramétereinek számításához. TDK thesis, Debrecen, 2014.

[3] Veszelszki K., Szeszák B. M.: Pneumobil gördülési ellenállásának vizsgálata. TDK, Debrecen 2016.

[4] Szeszák B. M., Sütő T. S.: Pneumobil gördülési ellenállásának vizsgálata terhelt állapotban, TDK, Debrecen, 2017.

[5] Szíki G. Á., Juhász Gy., Nagyné Kondor R., Szeszák B. M., Sütő S. T.: Analysis of the rolling resistance of pneumobiles for vehicle dynamic modelling purpose, Debrecen, 2018. 